\title{
The challenges of COVID-19 in medical education in Nepal
}

\author{
Paudel $\mathbf{V}^{1}$, Neupane $\mathbf{S}^{2}$
}

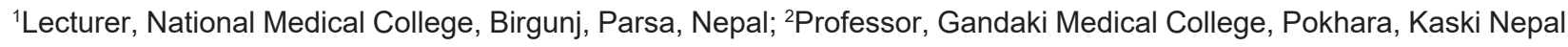

\begin{abstract}
The Coronavirus Disease-2019 (COVID-19) pandemic has caused an unparalleled disruption in all forms of scientific learning process including medical education. It has presented a challenge for scientists, educators, and students. Widespread interruptions to medical education, scientific discussions, conference, and seminars have also been seen at times of major conflicts and pandemics in the past as well, which resulted in major changes in medical curriculum. This editorial discusses the medical education and how COVID-19 has affected medical education in Nepal. Besides, it also explores the potential implications of COVID-19 for the future of medical education.

Key words: COVID-19; Education; Medical; Pandemics; Nepal
\end{abstract}

\section{The Coronavirus Disease 2019 (COVID-19) \\ pandemic has caused an unparalleled disruption} in all forms of scientific learning process including medical education, and healthcare all over the world. ${ }^{1}$ disease has caused deaths and serious comorbidities and it presents challenges for scientists, educators and students. ${ }^{2}$ Widespread interruptions to medical education, scientific discussion, conference and seminars have also been seen at times of major conflicts and pandemics in past as well which resulted in major changes in medical curricula. ${ }^{3}$

This discusses the current status of medical education in Nepal, describes how COVID-19 has affected medical education, theory and practical classes and internship learning environments, and explores the potential implications of COVID-19 for the future of medical education.

Most of the educational institutions including medical colleges and hospitals with teaching learning facilities in Nepal till the beginning of COVID-19 were based solely on traditional methods of learning, face-toface lectures in a classroom, direct patient encounter in outpatient departments and indoors. The sudden outbreak of COVID-19 shook the entire system leading to a complete change in teaching learning patterns,

Funding: No

Conflict of Interest: No

\section{Address of Correspondence}

Dr. Vikash Paudel

Department of Dermatology, National Medical College

Birgunj-19, Bhediyahi, Parsa, State 2, Nepal

+97798499948600

E-mail: vikashpoudel@iom.edu.np

ORCID ID: 0000-0001-8729-052X patient encounter, and physical distancing. As the World Health Organization declared it as a pandemic, it forced the educators to use e-learning platforms and change the traditional pedagogical approach to online teaching-learning, use of personal protective measures during patient examination and use of telemedicine. There has been an increase in telemedicine in various common diseases and emergency conditions as well. ${ }^{4}$ This tragedy has also shaken up the entire medical education and healthcare system, and this fear is resonating globally. ${ }^{5}$

The pandemic outbreak forced medical colleges and universities to remain closed completely or partially. Most of them have discontinued traditional teaching as social distancing is preeminent at this stage. The pandemic put people at risk of developing life-threatening conditions, presenting substantial challenges for medical education, clinical rotatory internship. Other challenges include a fear that medical students may contract the virus during their training and may transmit it to the community. Additionally, students are required to stay at home and to abide by social distancing guidelines. ${ }^{6}$

Submitted: $10^{\text {th }}$ December 2020

Accepted: $15^{\text {th }}$ January 2021

Published: $20^{\text {th }}$ February 2021

How to cite this article

Paudel V, Neupane S. The challenges of COVID-19 in medical education in Nepal. Nepal Journal of Dermatology, Venereology \& Leprology 2021;19(1):1-2. https://doi.org/10.3126/njdvl. v19i1.35308.

\section{(c) (i)}

Licensed under CC BY 4.0 International License which permits use, distribution and reproduction in any medium, provided the original work is properly cited. 
Besides medical education, these challenges have resulted in limited patient care due to the focus on COVID-19 patients, which restricts the availability of bedside teaching opportunities for medical students. Consequently, they are unable to complete their rotatory internship in the scheduled time. ${ }^{6}$ The medical licensing examinations have been cancelled and postponed. Recently, however, Tribhuvan University, Kathmandu University, and other institutions have instructed its affiliated colleges to run online classes for students and internship postings so that there would be no lag in the academic calendar. Similarly, scholarly conferences and seminars have been postponed or rescheduled on online platforms. ${ }^{7}$

\section{COVID-19 Affects the Teaching-Learning Environment}

Social distancing is the most effective Preventive strategy since the emergence of COVID-19 pending the development of a vaccine, treatment, or both. By definition, this precludes students from gathering in learning studios, lecture halls, or small group rooms. ${ }^{4}$

In response to COVID-19, medical education faculty have transitioned the entire curriculum to online formats that include content in the basic sciences, health systems, and even in behavioral sciences. Zoom, Google Meet, Microsoft Team and many other plat-forms are being used for online classes in a virtual room. Examinations have also transitioned to online settings. The transition from the workplace or medical school setting to home results in isolation, increased use of email among teachers, students, and support staffs. ${ }^{7}$

\section{References}

1. Rose S. Medical Student Education in the Time of COVID-19. JAMA 2020 Jun 2;323(21):2131-2132. https://doi.org/10.1001/jama.2020.5227

2. Emanuel EJ. The Inevitable Reimagining of Medical Education. JAMA 2020 Mar 24;323(12):11271128. https://doi.org/10.1001/jama.2020.1227

3. Barnett-Vanes $A$, Hassounah $S$, Shawki $M$, Ismail OA, Fung C, Kedia T, Rawaf S, Majeed A. Impact of conflict on medical education: a cross-sectional survey of students and institutions in Iraq. BMJ Open 2016 Feb 16;6(2):e010460. https://doi. org/10.1136/bmjopen-2015-010460

4. Paudel, V. The Increasing Scope of Teledermatology in Nepal. J Nepal Med Assoc 2020 Dec 31;58(232) https://doi.org/10.31729/jnma.5318
Internship postings as a direct encounter to the patient have been severely affected due to COVID-19 pandemic. There is a fear among students and clinicians that because of a highly contagious pandemic, students may transmit the virus unknowingly or contract the disease. Some other factors that limit the role of students are lack of familial support, lack of COVID-19 testing; diminished value of education, cancelation of surgery and the transition to telemedicine format, and lack of adequate personal protective equipment and its financial aspects. ${ }^{1}$

There is uncertainty regarding how long this situation will persists, but the situation is gradually changing. Various medical colleges have started internship posting by adopting social distancing, protective gears and limiting the number of patients and intern doctors as directed by universities, national medical boards in a "new normal" environment. With the discovery of new vaccines against SARS- COV-2, there is a glimpse of hope that medical education might return to its preCOVID era, but the online teaching learning platform might be incorporated in the existing systems as a hybrid in the curriculum. ${ }^{7}$

\section{Conclusion}

Amidst of this COVID-19 crisis, it is crucial as the academic educational community learn from the experience. The COVID-19 epidemic may represent an enduring transformation in medical education with the advancement of telemedicine a hybrid teaching learning process, and adaptive research protocols. Students and educators can analyze the effects of current changes in medical education to learn and apply new principles and practices to the future.

5. Sherchand JB. Effect of covid-19 pandemic on medical education in Nepal. Medphoenix 2020;5(1): 86-88 https://doi.org/10.3126/ medphoenix.v5i1.31429

6. Ahmed H, Allaf M, Elghazaly H. COVID-19 and medical education. Lancet Infect Dis 2020 Jul;20(7):777-778. https://doi.org/10.1016/ S1473-3099(20)30226-7

7. Piryani RM, Piryani S, Piryani S, Shankar RV, Shakya D. Impact of COVID-19 Pandemic on Medical Education: Challenges and Opportunities for Medical educators in South Asia. JBPKIHS 2020; 3(1): 28-38 https://doi.org/10.3126/jbpkihs. v3i1.30318 